\title{
TRENDS OF T. cruZi INFECTION BASED ON DATA FROM BLOOD BANK SCREENING ${ }^{1}$
}

Fabio ZICKER (2), Celina Maria Turchi MARTELLI (2), Ana Lucia Sampaio Sgambatti de ANDRADE (2) \& Simonne ALMEIDA E SILVA $(2)$.

\begin{abstract}
SUMMARY
Between October 1988 and April 1989 a cross-sectional survey was carried out in six out of eight blood banks of Goiania, Central Brazil. Subjects attending for first-time blood donation in the mornings of the study period $(n=1358$ ) were interviewed and screened for T. cruzi infection as a part of a major study among blood donors. Tests to anti-T. cruzi antibodies were performed, simultaneously, by indirect hemagglutination test (IHA) and complement fixation test (CFT). A subject was considered seropositive when any one of the two tests showed a positive result. Information on age, sex, place of birth, migration and socio-economic level was recorded. Results from this survey were compared with seroprevalence rates obtained in previous studies in an attempt to analyse trend of $\mathbf{T}$. cruzi infection in an endemic urban area. The overall seroprevalence of $\mathbf{T}$. cruzi infection among first-time donors was found to be $3.5 \%$ ( $95 \%$ confidence interval $2.5 \%-4.5 \%$ ). The seroprevalence rate increased with age up to 45 years and then decreased. Migrants from rural areas had higher seroprevalence rates than subjects from urban counties $(1.8 \%-16.2 \%$ vs. $0 \%-3.6 \%)$. A four fold decrease in prevalence rates was observed when these rates were compared with those of fifteen years ago. Two possible hypotheses to explain this difference were suggested: 1 . a cohort effect related with the decrease of transmission in rural areas and/or 2. a differential proportion of people of rural origin among blood donors between the two periods. The potential usefulness of blood banks as a source of epidemiological information to monitor trends of $\mathbf{T}$. cruzi infection in an urban adult population was stressed.
\end{abstract}

KEY WORDS: Trypanosoma cruzi; cross-sectional survey; blood bank screening.

\section{INTRODUCTION}

Few attention has been focused on the progressive urbanisation of Chagas' disease in Bra$\mathrm{zil}^{11}$. Large proportion of infected subjects have migrated from rural areas to inner cities looking for better condition of life. Population-based studies carried out among urban workers have shown a high prevalence of $\mathbf{T}$. cruzi infection and the impact of the disease in the Social Security System $^{5,13,14,15}$.

Blood transfusion transmission is one of the major implication of urban Chagas' disease and

(1) This investigation received financial support from CNPq (404230/88-1), and Secretaria de Ciência e Tecnologia/Ministério da Saúde $(001 / 89 \mathrm{MS} / \mathrm{UFG}$ ).

(2) Departamento de Saúde Coletiva. Instituto de Patologia Tropical e Saúde Pública/UFG. PO Box 12.063 . 74000 Goiânia. GO, Brazil. 
ZICKER, F.: MARTELLI, C. M. T.; ANDRADE, A. L. S. S. de \& ALMEIDA E SILVA, S. - Trends of T. cruzi infection based on data from blood bank screening. Rev. Inst. Med. trop. S. Paulo. 32(2): 132-137, 1990.

it has been considered the most difficult aspect of its control ${ }^{2,6}$. The risk of an effective transmission after a transfusion of $500 \mathrm{ml}$ of positive blood has been estimated to be around $12.5 \%$ to $25 \%{ }^{7}$. Although the screening for $T$. cruzi infected blood donors has been introduced as a health policy in Brazil several years ago, only a small proportion of blood banks are doing it properly. This problem has been exarcebated by the abusive practice of hemotherapy and by its commercial use.

The prevalence of $\mathbf{T}$. cruzi antibodies among blood donors is, however, the only routinely collected morbidity statistics on Chagas' disease. Several studies have reported a wide range of prevalence rates $^{8,12}$ but the data are usually poorly explored as a source of epidemiological information. The Chagas' disease Programme of the Ministry of Health is based exclusively on vector control and no information on prevalence of infection is routinely available nor is this monitored as part of the Programme.

A comparison of serological surveys conducted among blood donors from 1950 to 1980 in different areas showed that the prevalence has dropped in some regions, but remained constant in others ${ }^{7}$. The full understanding of $\mathbf{T}$. cruzi seroprevalence patterns and time trends depends on a comprehensive approach of the problem involving the study of hemotherapy services and donors in each locality.

In this study we compared data from a cross sectional survey carried out among blood donors in Goiânia, mid-west Brazil, with seroprevalence rates obtained in previous studies in an attempt to monitor trends of T. cruzi infection in an ende mic urban area.

\section{METHODS}

\section{Study Population}

Between October 1988 and April 1989 a cross-sectional survey was carried out in six of the eight blood banks of Goiânia (three private, two public and one charitable institution). These banks were responsible for approximately $90 \%$ of all blood collection in the city. Subjects attending for first-time blood donation in the mor nings of the study period ( $n=1358$ ) were intervie- wed and screened for T. cruzi infection. They corresponded to about $50 \%$ of the overall demand of first-time donation during the such pe riod. Usual donors, those who have donated blood before and, consequently, have already been screened, were not included in the present study to avoid a bias in the estimates of seroprevalence. The sample size of the survey was calculated based on an expected seroprevalence of $3.0 \%$ and accepting an standard error for a single proportion of $1 \%$.

The survey included all candidates to blood donation, independently of having previous history of malaria, Chagas' disease, syphilis and also included those individuals wishing to be tested for AIDS. Individuals belonging to the army and those attending blood donation campaign in any private company were excluded to avoid a selection bias. They represented less than $1 \%$ of candidates.

\section{Data collection}

Interviews were conducted by six trained interviewers, one in each blood bank, using a precoded questionnaire suitable for computer entry. Information on age, sex, place of birth, migration, socio-economic level (based on monthly income), contact with triatomid, blood transfusions and several risk factors for sexually transmitted disease (STD) were recorded. Part of the data will be included in a more comprehensive study of blood donors.

Blood samples were collected and tested to anti-T. cruzi antibodies, simultaneously, by indirect hemagglutination test (IHA) and complement fixation test (CFT). The laboratory tests were performed locally at each blood bank, using similar laboratory procedures and the same cutoff point for seropositivity. A subject was considered as "seropositive" when any of the two serological tests were positive (IHA Imunoserum ${ }^{*}$ test positive at a single dilution of 1:16 and/or CFT with a titre $>1: 16$ ).

\section{Statistical analysis}

The data were analysed using SPSS/PC (Statistical Package for Social Science). ChiSquare tests were calculated to measure difference in frequency, distribution, and, T-test and 
ZICKER, F.; MARTELLI, C. M. T.; ANDRADE, A. L. S. S. de \& ALMEIDA E SILVA. S. - Trends of T. cruzi infection based on data from blood bank screening. Rev. Inst. Med. trop. S. Paulo, 32(2): 132-137, 1990.

oneway analysis of variance to test differences between means.

\section{RESULTS}

The screened population consisted of persons of low socio-economic status, $87 \%$ males, most of whom were manual workers. The donors' mean age was 27.5 years (standard deviation ( $\mathrm{s}$. d.) 8.9$), 82.6 \%$ of them aged less than 36 years. Donors from different blood banks did not differ statistically in relation to age, sex, place of origin and socio-economic level.

The overall seroprevalence of $\mathbf{T}$. cruzi infection among candidates to donation was found to be $3.5 \%$ (95\% confidence interval (C.I.) 2.5-4.5). The prevalence rate increased with age up to 45 years and then decreased (Table 1 ). $51.9 \%$ of the donors came from the interior of the state of Goiás, $20.9 \%$ from Goiânia and the remaining (27.2\%) from other Brazilian States. The two serological tests presented a very high agreement in the results. Of those samples positive by IHA or CFT $90.2 \%$ were positive by both methods (copositivity).

Table 2 presents seroprevalence among blood donors born in Goiás by age group and origin, whether rural or urban. The overall prevalence of infection was $2.6 \%$, varying from $0 \%$ to $16.2 \%$ according to age and donors place of origin. As expected, people from rural areas have higher seroprevalence rates than subjects from urbans counties $(1.8 \%-16.2 \%$ vs. $0 \%-3.6 \%)$.

Table 3 shows the mean age and seroprevalence of $\mathbf{T}$. cruzi infection according to donors place of origin. The overall prevalence rate of

TABLE 1

Seroprevalence of $\mathbf{T}$. cruzi infection by age-group among firsttime blood donors in Goiânia-GO, Brazil, 1988-1989'.

\begin{tabular}{crc}
\hline Age (years) & Positive/Tctal & Prevalence $^{2}$ \\
\hline$\leq 25$ & $9 / 716$ & $1.3 \%$ \\
$26-35$ & $22 / 406$ & $5.4 \%$ \\
$36-45$ & $13 / 159$ & $8.2 \%$ \\
$\geq 46$ & $3 / 77$ & $3.9 \%$ \\
\hline Total & $47 / 1358$ & $3.5 \%$ \\
\hline
\end{tabular}

1 expressed as number of positive subjects/total number of subjects.

2 chi-squared for trend $=15.1, \mathrm{p}<0.01(25-45$ years $)$
TABLE 2

Seroprevalence of $T$. cruzi infection among blood donors born in Goiás, by age group according to urban or rural origin. Goia nia - GO, Brazil, 1988:1989'

\begin{tabular}{|c|c|c|c|c|c|}
\hline & \multirow{2}{*}{$\begin{array}{l}\text { Age } \\
\leq 25\end{array}$} & Urban origin & Rural origin & \multicolumn{2}{|c|}{ Total: } \\
\hline & & $2 / 463 \quad(0.4 \%)$ & $2 / 112 \quad(1.8 \%)$ & $4: 575$ & $(0.7 \%)$ \\
\hline & $26-35$ & $7 / 193 \quad(3.6 \%)$ & $17.3 \% 1$ & $14: 289$ & $(4.8 \%)$ \\
\hline & $36-45$ & I. $50 \quad(2.0 \%)$ & 6: $37(16.2 \%)$ & 787 & $(8.0 \%)$ \\
\hline & $\geq 46$ & $0.24 \quad(0.0 \%)$ & $1 ! 14 \quad(7.1 \%)$ & 138 & $(2.6 \%)$ \\
\hline & Total & $10 / 730 \quad(1.4 \%)$ & $16 / 259$ & $26 ; 989$ & $\left(2.6^{\prime} \pi\right)$ \\
\hline & $\begin{array}{l}\text { expres } \\
\text { subject }\end{array}$ & is number o & sitive subjec & total nu & 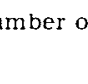 \\
\hline
\end{tabular}

TABLE 3

Mean age and prevalence of $T$. cruzi infection among first-time blood donors, according to place of origin, Goiania, 1988-1989.

\begin{tabular}{lcccc}
\hline \multicolumn{1}{c}{ Place of origin } & $\mathrm{n}$ & age (s.d.) & Prevalence \\
\hline State of Goiás & & & & \\
Goiánia & 284 & 23.2 & $(5.5)$ & $0.4 \%$ \\
urban counties & 446 & 27.0 & $(8.6)$ & $2.0 \%$ \\
rural areas & 259 & 28.7 & $(8.4)$ & $6.2 \%$ \\
Other States & 369 & 30.8 & $(9.9)$ & $5.7 \%$ \\
\hline Total & 1358 & 27.5 & $(8.9)$ & $3.5 \%$ \\
\hline
\end{tabular}

s.d. = standard deviation

infection was $6.2 \%$ for those who came from rural areas of Goiás and $2.0 \%$ for those who were born and have lived in inner cities. Individuals who were born and lived in Goiânia were younger (23.2, s.d. $5.5, \mathrm{p}<0.01$ ) than migrants and had lower seroprevalence $(0.4 \%, \mathrm{p}<0.01)$. Migrants from other Brazilian States had a mean age of 30.8 years (s.d. 9.9) and a seroprevalence of $5.7 \%$.

\section{DISCUSSION}

In Goiás, only two studies have reported pre valence rates of Chagas' disease among blood donors. The first study referred to a prevalence of $10.4 \%$ in complement fixation test (CFT), estimated among 4,372 blood donations in the period of 1962 to 1971 , in the University Hospital ${ }^{4}$. The second study, conducted fifteen years later (1985-1987) in five blood banks of the same city, showed a mean prevalence of $3.0 \%$ and $3.3 \%$ of anti-T. cruzi antibodies by CFT and IHA, respectively, in a total of 62,814 blond donations. No 
ZICKER, F.: MARTELLI, C. M. T.: ANDRADE, A. L. S. S. de \& ALMEIDA E SILVA, S. - Trends of T. cruzi infection based on data from blood bank screening. Rev. Inst. Med. trop. S. Paulo, 32(2): 132-137, 1990.

significant difference in prevalence was found between the donors from private and public blood banks in that study ${ }^{3}$.

In the present survey a similar figure to the last study was obtained and an overall seroprevalence of $3.5 \%$ (95\% C.I. 2.5-4.5) was estimated for first-time donors. Apparently, this result confirms the decrease of Chagas' disease infection in the last two decades in the city.

Considering that no important difference occurred in the screening policy nor in the laboratory techniques or in the donors population between the first survey and the two others, two hypotheses might be proposed to explain the decrease in the prevalence of infection.

First, assuming that the transmission in rural areas have really dropped over time due to vector control' ${ }^{9}$, we would expect that each new generation of donors would have lower rates of infection (cohort effect). People donating blood at a given time would be lesser infected than those in previous years. This was, in fact, confirmed by the present study, since T. cruzi seroprevalence rates increased with age. The decrease of prevalence in subjects aged 45 years and more might be explained by a selective exclusion of infected and diseased subjects from the donors population. This effect has been also reported in a population-based survey conducted among urban workers in Goiânia ${ }^{16}$.

If the proportion of people from rural areas donating in blood banks was constant over time the crude overall seroprevalence estimates would be a reliable indirect estimation of $\mathbf{T}$. cruzi infection for the whole population.

A second possible explanation for the decrease of the seroprevalence would be related with the migration and development of the State. The population of Goiás grew at rates of $12.8 \%$, $10.8 \%, 6.6 \%$ and $3.9 \%$ per decade, from 1940 to 1980 , respectively ${ }^{1}$. In early years most of the growth was due to rural-urban migration and this has certainly changed. For this reason the drop in prevalence rates observed among blood donors might reflect not only the decrease of infection in rural areas but also differences in the proportion of people with rural origin among blood donors. Since the two previous surveys did not show specific prevalence rates for people from rural and urban the comparison is not straightforward. Moreover, if the proportion of infected people leaving rural areas in direction to urbanised regions is still the same they would be now less representative in terms of the overall population because presently the rural component of internal migration is not so important as in the past.

Only 284 ( $20.9 \%$ ) of the 1358 first-time donors were born and were living in Goiânia. Although they had the lowest prevalence rate $(0.4 \%)$ the possibility of $\mathbf{T}$. cruzi transfusional transmission can not be discharged since the chance of vector transmission in urban area is remote. The highest prevalence rate was obtained for those in dividuals who have migrated from rural areas of Goiás. This shows the impact of the rural com ponent of the population in the estimates of prevalence. This was also reported in blood donors of Sobradinho, Federal District, in the late $60 \mathrm{~s}$. The importance of the rural-urban migration for the increased prevalence of $\mathbf{T}$. cruzi infection among blood donors in urban area has been em phasised and a dilution of seropositivity has been predicted to occur after the settlement of Brasillia $^{10}$.

Both hypotheses, different cohorts in relation to infection and rural-urban migration differences are related with the development of central Brazil. We have to admit that based exclusively on the data available it is not possible to have a satisfactory interpretation of trends in $\mathbf{T}$. cruzi infection. Moreover, blood donors are a self-selective group of people and this limits the generalisation of the data.

The seroprevalence estimates for this study were based on the laboratory results provided by the blood banks. We understand that this should be the ideal public health strategy for monitoring disease trends. Certainly, we can not assure the precision of the diagnosis tests employed and we believe that carefully studies for standardise and validate serological tests on blood banks should be conducted if such information system is desired.

We have shown that the screening of blood donors could be a valuable source of information of T. cruzi infection when data are collected and 
ZICKER, F.; MARTELLI, C. M. T.; ANDRADE, A. L. S. S. de \& ALMEIDA E SILVA, S. - Trends of T. cruzi infection based on data from blood bank screening. Rev. Inst. Med. trop. S. Paulo, 32(2): 132-137, 1990.

analysed in a standardised way. Age, sex and place of origin-specific seroprevalence rates should always be calculated in order to have a reliable indicator to monitor trends of $\mathbf{T}$. cruzi infection in urban adult population at a low cost.

\section{RESUMO}

\section{Monitorização da infecção pelo $T$. cruzi através do rastreamento sorológico em bancos de sangue.}

Dados de soroprevalência para doença de Chagas em primo-doadores de sangue obtidos num estudo seccional foram comparados com estimativas prévias obtidas há 15 anos na mesma população no intuito de estudar tendência temporal da infecção pelo T. cruzi.

Durante o período de outubro de 1988 à abril de 1989, 1358 primo-doadores de sangue em seis dos oito bancos de sangue de Goiânia-Goiás foram rastreados sorologicamente para detecçāo de anticorpos anti-T. cruzi pelas técnicas de Hemaglutinação indireta (IHA) e Fixação de Complemento (FC). Os doadores foram entrevistados colhendo-se informações sobre idade, sexo, naturalidade, história de migração e nível sócio-econômico para a estimativa de soroprevalências específicas.

Foi obtida uma prevalência global de 3,5\% (limites de confiança $95 \%, 2,5-4,5$ ), detectando-se um aumento de prevalência com a idade até os 45 anos e posterior decréscimo. Indivíduos procedentes de zona rural apresentaram taxas de soroprevalências superiores aquelas obtidas entre os doadores de área urbana $(1,8 \%-16,2 \%$ vs. $0 \%-3,6 \%$ ). Foi observado um decréscimo de quatro vezes na taxa de prevalência global quando se comparou os resultados atuais com estimativas obtidas nos estudos anteriores. Duas hipóteses foram sugeridas para explicar a variação de prevalência: 1 . um efeito "coorte" relacionado ao decréscimo da transmissão em áreas rurais e/ou 2. diferenças na composição urbano-rural da população de doadores nos diferentes períodos de estudo. Foi enfatizada a utilização do rastreamento sorológico realizado de rotina pelos bancos de sangue como fon te de informação epidemiológica para monitorizar tendência da infecçāo pelo T. cruzi.

\section{ACKNOWLEDGEMENTS}

We are grateful to Drs. Cesar Leite-Santana, Edmo Dias Pinheiro, Antonia Oliveira Nazareno, Francisco Pereira Borges, blood banks directors, and to Miss Graciara B. Brito, Mr. Jales T. Chaves Filho and Miss Ana Maria C. Primio for their technical assistance with data processing.

\section{REFERENCES}

1. ANUÁRIO Estatístico do Brasil. Rio de Janeiro, IBGE, 1987.

2. AMATO NETO, V. - Doença de Chagas pós-transfusional. Rev. Hosp. Clín. Fac. Med. S. Paulo, 43: 135.137, 1988 .

3. ANDRADE, A. L. S. S.; MARTELLI, C. M. T.; PINHEIRO E. D.; SANTANA, C. L.; BORGES, F. P. G. \& ZICKER F. - Rastreamento sorológico para doenças infecciosas em banco de sangue como indicador de morbidade populacional. Rev. Saúde públ. (S. Paulo), 23: 20-25, 1989.

4. CAMPOS, C.; REZENDE, J. M. \& RASSI, A. - Preva lência da doença de Chagas no banco de sangue do Hospital das Clinicas de Goiânia. Possibilidade de falha da reaçāo de Machado Guerreiro na seleção de doadores. Rev. Soc. bras. Med. trop., 9: 165-174, 1975

5. COURA, J.R.-Doença de Chagas como endemia urbana. In: CANÇADO, J. R. \& CHUSTER, M. - Cardiopatia chagásica. Belo Horizonte, Ed. Fundaçảo Carlos Chagas de Pesquisa Médica, 1985. p. 356-361.

6. DIAS, J. C. P. - Análise e perspectiva do controle da doença de Chagas no Brasil. Rev. bras. Malar., 35: $109-119,1983$

7. DIAS, J.C.P.\& BRENER, S. - Chagas' disease and blood transfusion. Mem. Inst. Oswaldo Cruz, 79: 139-147, 1984

8. DIAS, J. C. P. - Mecanismos de transmissão. In: BRENER, Z. \& ANDRADE, Z. - Trypanosom a cruzi e doença de Chagas.. Rio de Janeiro, Guanabara Koogan, 1979. p. $152-174$.

9. GARCIA-ZAPATA, M. T.; MARSDEN, P. D.; VIRGENS, D.; PENNA, R.; SOARES, V; BRASIL, A; CASTRO, C N.: PRATA, A. \& MACEDO, V. - O controle da transmissão da doença de Chagas em Mambai-Goiás, Brasil (1982-1984). Rev. Soc. bras. Med. trop., 19: 219-225, 1986.

10. LIMA, L. M. A. de: SACRAMENTO, H. S.; GAMA, M. P G. \& MUNIZ, J. D. - Inquérito sorológico para doença de Chagas em doadores de sangue na Unidade Integrada de Sobradinho (UISS), D. F. Rev. goiana Med., 27: 201-215, 1981

11. Silva, G. R.; LiTVOC, J.; GOLdBAUM, M. \& DiAs, J C. P. - Aspectos da epidemiologia da doença de Chagas. Ciênc. e Cult., 31 (supl): 81-104. 1979. 
ZICKER, F.; MARTELII, C. M. T.; ANDRADE, A. L. S. S. de \& ALMEIDA E SILVA, S. - Trends of T. cruzi infection based on data from blood bank screening. Rev. Inst. Med. trop. S. Paulo, 32(2): 132-137, 1990.

12. SCHLEMPER, JR, B. R. - Estudos experimentais de quimioprofilaxia da transmissāo da doença de Chagas por transfusāo sangüinea. Rev. Pat. trop. 7: 55-111, 1978.

13. ZICKER, F. \& ZICKER, E. M. S. - Benefícios previdenciários por incapacidade como indicador de morbidade: estudo da doença de Chagas em Goiás. Rev. goiana Med., 32: 125-36, 1986

14. ZICKER, F. - Chagas' disease and social security. A casecontrol study in an urban area, Goiás, Brazil. Rev. Saúde públ. (S. Paulo), 22: 281-287, 1988.
15. ZICKER, F.; LUQUETTI, A. O.; OLIVEIRA, R. M. \& SMITH, P. G. - Seroprevalence of Chagas' disease among urban unskilled workers in central Brazil. Trans. roy. Soc. trop. Med. Hyg., 83: 511-513, 1989.

16. ZICKER, F.; ALMEIDA NETTO, J. C.; ZICKER, E. M. S.; OLIVEIRA, R. M. \& SMITH, P. G. - Trypanosoma cruzi infection and electrocardiographic findings among active manual workers. A population-baseo study in cen tral Brazil. Int. J. Epidem. 19: 182-186, 1990

Recebido para publicaçāo em 10/8/1989 